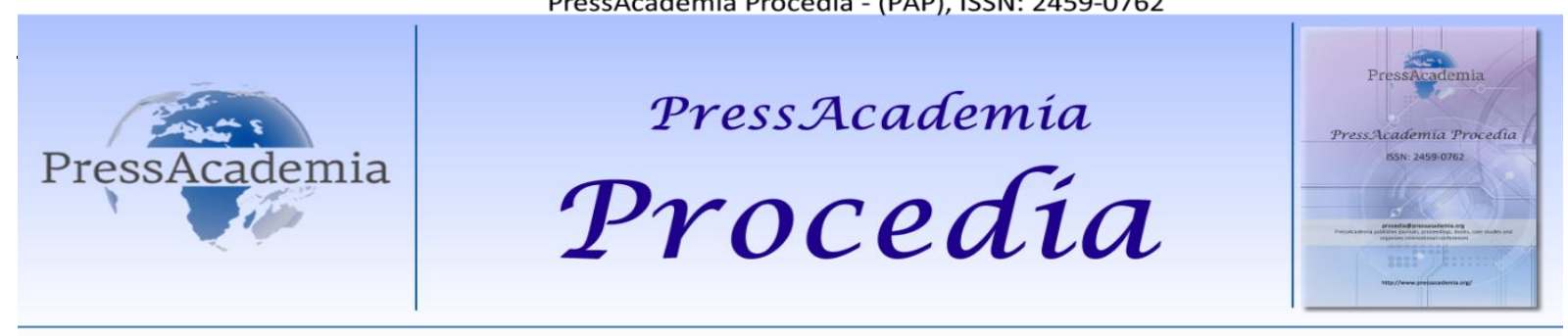

Global Business Research Congress (GBRC), May 24-25, 2017, Istanbul, Turkey.

\title{
EFFICIENCY AND PRODUCTIVITY OF TURKISH SECURITIES FIRMS: 2011-2015
}

\section{DOI: 10.17261/Pressacademia.2017.394 \\ PAP-GBRC-V.3-2017(9)-p.75-80}

\author{
Oktay $\operatorname{TaS}^{1}$, Gokben Cevikcan ${ }^{2}$ \\ ${ }^{1}$ İstanbul Teknik Üniversitesi, oktay.tas@itu.edu.tr \\ ${ }^{2}$ İstanbul Teknik Üniversitesi, gokbenaltas@gmail.com
}

To cite this document

Tas, O. and G. Cevikcan, (2017). Efficiency and productivity of Turkish securies firms:2011-2015. PressAcademia Procedia (PAP), V.3, p.7580.

Permemant link to this document: http://doi.org/10.17261/Pressacademia.2017.394

Copyright: Published by PressAcademia and limited licenced re-use rights only.

\begin{abstract}
Employing a Data Envelopment Analysis (DEA) approach, we investigate the technological progress, efficiency, and productivity of the Turkish securities firms between 2010 and 2015. After measuring the performance of these firms with DEA analysis, we combine the efficiency scores with contingency factors (ownership, size and bank affiliation) in a panel regression analysis in order to determine the effects. Our results indicate that the securities industry in general is less efficient than the existing technology allows. The relative productivity of the Turkish securities industry in general improved. Foreign acquisition has positive significant contribution to the efficiency of securities firms. Smaller firms, due to their inability to respond to technological innovation, experienced especially large decreases in both efficiency and productivity.
\end{abstract}

Keywords: Securities firms, efficiency, data envelopment analysis, panel regression, capital markets.

JEL Codes: G20, G23, G24

\section{INTRODUCTION}

Securities firms are one of the most important institutions in the financial system. They involved in securities markets perform established functions of buying and selling securities (brokerage) in both primary and secondary markets. The functions of these firms depend on the country practices, but they usually provide ancillary services in capital markets some of which underwriting and market making; financial advising and portfolio management. They may also engage investment banking activities such as assisting companies involved in mergers and acquisitions. As in many developing economies in Turkey, banks dominate the financial system and securities industry is still an emerging industry. Nevertheless, the Turkish capital market has been developing over the last decades thanks to several institutional reforms, infrastructure and regulatory enablers alongside economic development (Kartal, 2013). Unlike developed markets such as USA1, UK, or many EU countries, in Turkey securities firms can engage in main brokerage activities, i.e equity or futures transactions, which makes investigating these firms more remarkable.

\footnotetext{
${ }^{1}$ Banks could not involve in securities activities for a long time in the USA due to the Glass-Steagall Act of 1933, which prohibited a bank from offering investment banking, commercial banking, and insurance services together. In 1999, the USA passed the Gramm-Leach-Bliley Act, which repealed the Glass-Steagall Act and enabled banks, insurance companies, securities firms, and other financial institutions to affiliate under financial holding companies (FHCs). However in 2010 the Volcker rule (in Dodd-Frank Act) enacted which prohibits prevent banks from making risky speculative trading. The policy tried to replicate the separation between investment and commercial banking.
} 


\section{LITERATURE REVIEW}

As in other countries, although many studies analyse the performance of banks in Turkey, only a few studies examine the performance of securities firms. Whilst the Turkish banking sector has attracted interest from scholars (Demir, Mahmud, \& Babuscu, 2005; Aysan \& Ceyhan, 2008; Ihsan, 2007; Isik \& Hassan, 2008; Fukuyama \& Matousek, 2011) there has been comparatively little investigation of its securities industry (Aktas \& Kargin, 2007; Bayyurt \& Akın, 2014). This paper is one of the few studies in the literature related to the performance of securities firms.

Most of the past studies about the performance of securities firms investigate the factors influencing their efficiencies. Many of them attribute the superior performance of the securities firms to their sizes. Fukuyama and Weber (1999) examine the efficiency and productivity of Japanese securities firms during the period 1988-93 and they find that the bigger securities firms were more cost-efficient than smaller securities firms. Similarly Wang, Tseng and Weng (2003) assess pure technical, scale and allocative efficiencies of securities firms in Taiwan and they demonstrate that firm size has a positive impact on the efficiency measures. Aktas and Kargin (2007) analyze the efficiency and productivity of securities firms operating in Turkey during the period 2000-2005. They determine no considerable change in the efficiency and productivity of securities firms during the study period. Furthermore, they find that big-medium sized firms are more productive. Lee et al (2014) examine whether firm size determines the economies of scale and scope of securities firms in Korea. The results layout that the firms broadly achieved economies of scale and substantially benefitted from the economies of scope in the Korean brokerage sector.

There are also few studies investigate the influence of bank affiliation on the efficiency of securities firms. Chen et al (2005) study the impacts of government regulation and ownership on the performance of Chinese securities firms. They find that bank affiliated firms have higher efficiency scores. Hu and Fang (2010) measure the efficiency scores of securities firms in Taiwan between 2001 to 2008 . They show that foreign-affiliated ownership of those firms positively affects the efficiency scores.

Farrel for the first time suggest two approaches (parametric and nonparametric methods) to measure the efficiency of firms and during the past decades the studies developed along these paradigms (Serasigne et al, 2003). Nonparametric methods require minimal assumptions respect to structure of production and also they do not impose restrictions on the functional forms relating inputs and outputs. From parametric (econometric) methods, stochastic frontier analysis, Thick Frontier Analysis and Distribution Free Analysis can be mentioned. Data envelopment analysis (DEA) and Free Distribution Hull are nonparametric models and so require minimal assumptions respect to structure of production and also they do not impose restrictions on the functional forms relating inputs and outputs.

The DEA approach introduced by Charnes et al (1978) uses a linear programming technique to determine a pricewise linear envelopment surface from the observed levels of inputs and outputs of decision making units (Wang et al 2003). In this paper, we mainly focus on DEA efficiency measures and combine the efficiency scores with contingency factors (ownership, size and bank affiliation) in a panel regression analysis in order to determine the effects.

The research framework is as follows: Following a brief review of capital markets in Turkey in section 2, we describe the methodology and the data in section 3. Section 4 reports the empirical findings and analysis thereof. Section 5 is final conclusions and recommendations.

\section{The Turkish Securities Industry}

The establishment of a modern securities market in Turkey dates back to the 1980's when a macro-economic approach aiming to liberalize the country's economy was adopted (TCMA 2009). The capital market regulations have been created by a new understanding, and the relevant institutions and instruments have been formed accordingly. During this period, the number of securities firms has increased dramatically until 2000s. However, meeting the high public sector borrowing demands by the financial markets until the beginning of the 2000s, the frequent economic instabilities, the high interest rates and the low propensity to save has created pressure on the markets, this situation has prevented or postponed the development of capital markets.

Chart 1: Total Number of Securities Firms in Turkey

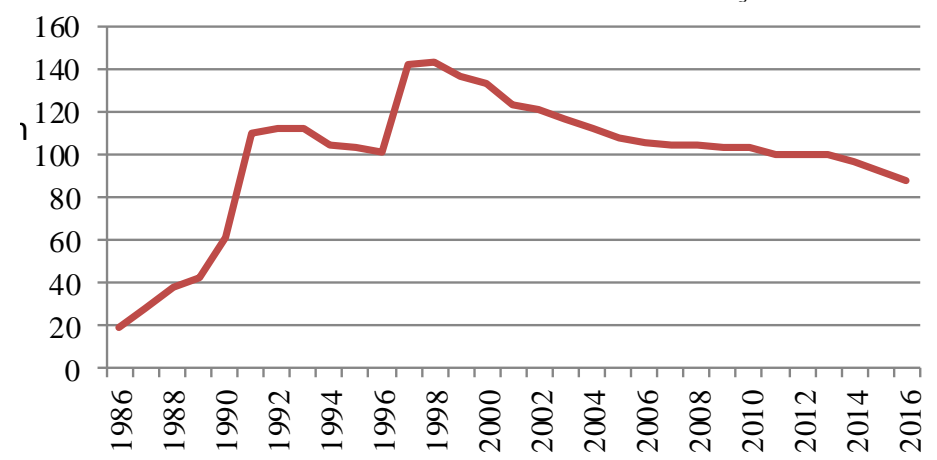


Table 1: Literature Review on Measuring Efficiency of Securities Firms

\begin{tabular}{|c|c|c|c|c|c|c|c|}
\hline \multirow{2}{*}{$\begin{array}{l}\text { Name } \\
\text { Fukuyama et al }\end{array}$} & \multirow{2}{*}{$\begin{array}{l}\text { Year } \\
1999\end{array}$} & \multirow{2}{*}{$\begin{array}{l}\text { Time Horizon } \\
1988-1993\end{array}$} & \multirow{2}{*}{$\begin{array}{l}\text { Country } \\
\text { Japan }\end{array}$} & \multicolumn{3}{|c|}{ Methodology } & \multirow{2}{*}{$\begin{array}{l}\text { Conclusion } \\
\text { Big four securities companies were more cost-efficient than } \\
\text { smaller ones. Overall cost efficiency remained constant during } \\
\text { the research period (1988-1993) }\end{array}$} \\
\hline & & & & $\begin{array}{l}\text { DEA + Malmquest Index (compare efficiency } \\
\text { change during the research period) }\end{array}$ & $\begin{array}{c}\text { Input } \\
\text { - Labor (number) } \\
\text { - Physical capital }\end{array}$ & $\begin{array}{l}\text { Output } \\
\text { - Brokerage revenue } \\
\text { - Underwriting revenue }\end{array}$ & \\
\hline Wang et al & 2003 & 1991-1993 & Taiwan & $\begin{array}{l}\text { DEA + Tobit (for examining the relationship } \\
\text { between each efficiency measure and firm } \\
\text { specific } \\
\text { attributes - i.e firm size, service composition, } \\
\text { having brunch ) }\end{array}$ & $\begin{array}{c}\text { Input } \\
\text { - Labor (number) } \\
\text { - Capital (floor area of office) }\end{array}$ & $\begin{array}{l}\text { Output } \\
\text { - Brokerage revenue } \\
\text { - Equity dealing revenue } \\
\text { - Underwriting revenue }\end{array}$ & $\begin{array}{l}\text { The authors report that report that smaller regional firms } \\
\text { experience large decreases in both efficiency and productivity. } \\
\text { They also mention that the firm size has a positive impact on } \\
\text { efficiency scores due to the existence of scale economies and } \\
\text { the advantage from joint use of inputs. }\end{array}$ \\
\hline Chen et al & 2005 & $1999-2000$ & China & \multicolumn{3}{|c|}{$\begin{array}{l}\text { Ratio Analysis + Regression analysis (profitability-ROE- as dependent variable whilst leverage, asset size and } \\
\text { the government ownership as independent variables) }\end{array}$} & $\begin{array}{l}\text { Results show that direct investment from government will } \\
\text { reduce a firm's profitability. The authors suggest to reduce } \\
\text { state ownership in this industry which may lead to better } \\
\text { corporate governance and improved financial performance in } \\
\text { the long run. }\end{array}$ \\
\hline Zhang et al & 2006 & $1980-2000$ & USA & $\begin{array}{l}\text { DEA + Malmquest Index (compare efficiency } \\
\text { change during the research period) }\end{array}$ & $\begin{array}{l}\text { Input } \\
\text { - Labor (compensation) } \\
\text { - Capital (non-labor, non-interest } \\
\text { expense) } \\
\text { - Equity. }\end{array}$ & $\begin{array}{l}\text { Output } \\
\text { - Commission } \\
\text { - Market making rev. } \\
\text { - Investment bank. rev - } \\
\text { Asset mang. rev. } \\
\text { - Total Revenue }\end{array}$ & $\begin{array}{l}\text { Results indicate that the US securities industry in general is } \\
\text { quite cross-sectionally inefficient. The relative productivity of } \\
\text { the US securities industry in general declined. They also state } \\
\text { that smaller regional firms, due to their inability to respond to } \\
\text { technological innovation are less efficient. }\end{array}$ \\
\hline Aktaş and Kargın & 2007 & $2000-2005$ & Turkey & $\begin{array}{l}\text { DEA + Malmquest Index (compare efficiency } \\
\text { change during the research period) }\end{array}$ & $\begin{array}{c}\text { Input } \\
\text { - Equity } \\
\text { - Operating Industry }\end{array}$ & $\begin{array}{c}\text { Output } \\
\text {-Equity transactions } \\
\text { - Brokerage Commissions }\end{array}$ & $\begin{array}{l}\text { Results show that larger firms are more efficient. The } \\
\text { efficiency has decreased overall during the research period. }\end{array}$ \\
\hline Hu \& Fung & 2010 & 2001-2005 & Taiwan & $\begin{array}{l}\text { DEA zero sum game (maximizing the market } \\
\text { share to analyse the competition among } \\
\text { securities firms in Taiwan) }\end{array}$ & $\begin{array}{l}\text { Input } \\
\text { - Labor (number) } \\
\text { - Financial Capital }\end{array}$ & $\begin{array}{l}\text { Output } \\
\text { - Market Share }\end{array}$ & $\begin{array}{l}\text { The empirical results indicate that firms with larger market } \\
\text { shares achieve higher efficiency scores. The authors suggest } \\
\text { that mergers among large-sized financial institutions should be } \\
\text { encouraged in order to increase market shares and efficiency } \\
\text { scores. }\end{array}$ \\
\hline Bayyurt and Akın & 2014 & $2010-2011$ & Turkey & $\begin{array}{l}\text { DEA + Panel regression (used to determine the } \\
\text { effects of foreign acquisitions on the } \\
\text { efficiency.) }\end{array}$ & $\begin{array}{c}\text { Input } \\
\text { - Labor (number) } \\
\text { - Operating expense }\end{array}$ & $\begin{array}{l}\text { Output } \\
\text { - Brokerage revenue } \\
\text { - Other revenue }\end{array}$ & $\begin{array}{l}\text { Results indicate that foreign acquisition has positive significant } \\
\text { effect on the efficiency of securities firms. This positive effect } \\
\text { is observed in the early years of acquisition and it gets higher } \\
\text { in the later years. }\end{array}$ \\
\hline Lee et al & 2014 & $2000-2007$ & Korea & \multicolumn{3}{|c|}{$\begin{array}{l}\text { Estimation with Cobb-Douglas (hybrid, translog and quadratic cost functions used separately) production } \\
\text { function. } \\
\text { (commission revenue determined by multiplying the commission rates with the total service amount for } \\
\text { different service types i.e- brokerage, prop trading, wealth management) }\end{array}$} & $\begin{array}{l}\text { Results showed that the firms broadly achieved economies of } \\
\text { scale and substantially benefitted from the economies of } \\
\text { scope. The authors posits that, larger securities firms, may } \\
\text { benefit from M\&A due to the economy of scale. }\end{array}$ \\
\hline
\end{tabular}


The securities industry benefited from improved economic conditions and decreased need for public borrowing in last ten to fifteen years. Other debt instruments had a chance to find a place in the capital market besides the public debt instruments; and a relatively diversification has been achieved in terms of both issuers and investors in the capital market during this period. Nevertheless, the number of brokerage firms has reduced during this period. As the capital markets develop, the corporate structure of the securities firms has improved (in terms of capital adequacy etc.) which result in consolidation in the sector and the number of these firms has reduced. The liberalization of brokerage commission in 2006 and falling fees also has effect on the decreasing number of firms.

By the way, the sector has faced many structural changes at a time when the global economy is faced with numerous challenges. The new Capital Markets Law came into force in 2012. The new law aims to align the regulations in Turkey with those of the European Union and strengthens investor protection. The new law has also increased

Table 2: Turkish Securities Firms at a Glance

\begin{tabular}{lrrrrr}
\hline & $\mathbf{2 0 1 1}$ & $\mathbf{2 0 1 2}$ & $\mathbf{2 0 1 3}$ & $\mathbf{2 0 1 4}$ & $\mathbf{2 0 1 5}$ \\
\hline Total Assets ( TL, mn.) & 8.049 & 11.367 & 13.987 & 15.132 & 15.312 \\
Current Assets & 7.306 & 10.346 & 12.964 & 14.138 & 14.242 \\
Equity & 2.769 & 3.059 & 3.337 & 3.659 & 4.010 \\
\hline Total Revenue & 1.161 & 1.128 & 1.394 & 1.588 & 2.001 \\
$\quad$ Brokerage Revenue & 872 & 792 & 1.023 & 1.157 & 1.484 \\
Operating Profit (TL, mn.) & 305 & 115 & 226 & 281 & 301 \\
Net Profit & 414 & 275 & 529 & 372 & 433 \\
$\quad$ Return on Equity & $15 \%$ & $9 \%$ & $16 \%$ & $10 \%$ & $11 \%$ \\
\hline Labour (number) & 5.100 & 5.258 & 5.480 & 5.657 & 6.639 \\
\hline Number of Firms & 93 & 97 & 95 & 85 & 74 \\
\hline Affiliate & & & & & \\
$\quad$ Bank affiliated & 22 & 22 & 22 & 21 & 21 \\
$\quad$ Independent & 71 & 75 & 73 & 64 & 53 \\
\hline Ownership & & & & & \\
$\quad$ Domestic & 68 & 72 & 70 & 60 & 52 \\
$\quad$ Foreign & 25 & 25 & 25 & 25 & 22 \\
\hline
\end{tabular}

The general framework of Turkish Securities industry (in research period) is given in Table 2. As shown the table, The major revenue source of the industry is brokerage commissions. Brokerage firms generated two third of their revenues from brokerage commissions.

\section{DATA AND METHODOLOGY}

Data set of securities firms are obtained from Turkish Capital Markets Association (TCMA). We focus on active securities firms (having trading volume) in last 5 years (between 2011 and 2015).

Since multiple inputs and outputs for securities firms are used in the analysis, DEA is an appropriate technique to measure relative efficiency. To facilitate the empirical analysis, we use the following input and output variables. Our input variables are: (1) equity (2) labor (number) while the output variables are (1) total revenue per employee (2) net income per employee (3) return on equity. The selection of these inputs and outputs are guided by the prior literature on securities firms' efficiency as listed in Table 1.

Data Envelopment Analysis presents and solves the following linear programming problem for each firm. (Bayyurt and Akın, 2014).

$$
\begin{aligned}
& \text { Maxh }_{o}=\sum_{r=1}^{S} u_{r} Y_{r o} \\
& \text { subject to } \\
& \sum_{i=1}^{m} v_{i} X_{i o}=1 \\
& \sum_{r=1}^{S} u_{r} Y_{r k}-\sum_{i=1}^{m} v_{i} X_{i k} \leq 0 \\
& u_{r}, v_{i} \geq \varepsilon, \quad k=1, \ldots, n, r=1, \ldots, \text { s and } i=1, \ldots, m
\end{aligned}
$$

where $X_{i j}$ and $Y_{r j}$ stand for the amount of $i$-th input and $r$-th output decision making unit (DMU) respectively. $V_{i j}$ and $n_{r j}$ are the weights of $r$-th output when $\mathrm{j}$-th $\mathrm{DMU}$ is under consideration. $\mathrm{N}$ is the number of the sample. $\mathrm{s}$ is the number of outputs and the number of inputs that the analyzed firm produces and utilizes respectively. $\varepsilon$ is a very small positive number which 
ensures that every input and output has a value greater than zero. In this form, the most favourable weight set for $\mathrm{DMU}_{0}$ is chosen, which maximizes the weighted sum of outputs of $\mathrm{DMU}_{0}$. The model is the original formulation represented in Charnes et al. (1978).

In this study, a constant return to scale is assumed. The duality component of this model is an input oriented model since it points out the inefficiencies in the input consumption of $\mathrm{DMU}_{0}$.

The descriptive statistics of the input and output variable is represented Table 3.

Table 3: Descriptive Statistics of Input and Output

\begin{tabular}{lrrrrr}
\hline & $\mathbf{2 0 1 1}$ & $\mathbf{2 0 1 2}$ & $\mathbf{2 0 1 3}$ & $\mathbf{2 0 1 5}$ & $\mathbf{2 0 1 5}$ \\
\hline Avg. Labor (number) & 55 & 54 & 58 & 67 & 90 \\
Avg. Equity (TL, mn.) & 29,8 & 31,5 & 35,1 & 43,0 & 54,2 \\
\hline Avg. Total Revenue per Employee (TL) & & & 249.633 & 284.510 & 341.691 \\
Avg. Net Income per Employee (TL) & & & 96.445 & 64.649 & 47.048 \\
Return on Equity (\%) & $15 \%$ & $9 \%$ & $16 \%$ & $10 \%$ & $11 \%$ \\
\hline Number of Firms & 93 & 97 & 95 & 85 & 74 \\
\hline
\end{tabular}

Following this analysis, the efficiency scores from the DEA (dependent variable) are combined with contingency factors in a panel regression analysis in order to determine the effects. These contingency factors (independent variables) are bank affiliation (affiliated/independent: dummy variables are used, affiliated is based), ownership difference (domestic /foreign: dummy variables are used; foreign is base) the size (natural logaritm of assets). Finally, as leveraged forex transactions have become important revenue for this sector during the research period, this activity is also considered. Dummy variables are used, forex firms is based.

The regression model is specified as below.

Efficiency $_{i t}=\beta_{0}+\beta_{1}$ size $_{i t}+\beta_{2}$ affiliated $_{i t}+\beta_{3}$ foreign $_{i t}+\beta 4$ forex $_{i t}+\varepsilon_{\text {it }}$

\section{FINDINGS AND DISCUSSIONS}

Table 4 gives the summary of the results of data envelopment analysis between 2011 and 2015. The average efficient score is around \%28 to \%35. Although the industry has experienced a consolidation during the research period, the efficiency has not improved dramatically.

Whilst bank- affiliated firms score is \%39, the other securities firms' (which is 3 times of bank affiliate firms in terms of number) efficiency score is \%30. Bank affiliated securities firms' efficiency scores is $30 \%$ higher than the independent ones. With average $45 \%$ efficiency score, the most efficient firms are the firms that have $50 \%$ and more foreign ownership. It is important to note that, the forex companies efficiency scores are also higher, and the efficiency is improved between 2011 and 2015.

Table 4: Descriptive Statistics of Efficiency Scores

\begin{tabular}{lrrrrr}
\hline & Number & Mean & $\begin{array}{r}\text { Standard } \\
\text { Dev. }\end{array}$ & Min. & Mak. \\
\hline 2011 & 93 & 0,3458 & 0,2296 & 0,039 & 1 \\
2012 & 97 & 0,2715 & 0,2819 & 0,028 & 1 \\
2013 & 95 & 0,3512 & 0,3015 & 0,031 & 1 \\
2014 & 85 & 0,3489 & 0,2789 & 0,036 & 1 \\
2015 & 74 & 0,3529 & 0,3215 & 0,027 & 1 \\
\hline Bank Affiliated & 108 & 0,3896 & 0,1598 & 0,135 & 1 \\
Independent & 336 & 0,2996 & 0,2015 & 0,015 & 1 \\
\hline Domestic & 307 & 0,1518 & 0,1892 & 0,014 & 1 \\
Foreign & 137 & 0,4596 & 0,2573 & 0,189 & 1 \\
\hline Forex & 59 & 0,4216 & 0,3526 & 0,259 & 1 \\
Other & 385 & 0,3119 & 0,3013 & 0,015 & 1 \\
\hline
\end{tabular}

The initial efficiency scores created through DEA were inputted to a panel regression analysis to examine the effect of the firm's structure on its efficiency. Since the analysis deal with the whole population, the fixed effects panel regression is employed. 


\section{REFERENCES}

Aktas, H., \& Kargin, M. (2007). Efficiency and productivity of brokerage houses in Turkish capital market. Iktisat Isletme ve Finans, $22,97$.

Bayyurt, N., \& Akın, A. (2014). Effects of foreign acquisitions on the performance of securities firms: evidence from Turkey. ProcediaSocial and Behavioral Sciences, 150, 156-161Ashton JK (2001). Cost efficiency characteristics of British retail banks. Serv Indust J 21: 159174

Charnes, A., Cooper, W. W., \& Rhodes, E. (1978). Measuring the efficiency of decision making units. European Journal of Operational Research, 3, 429-444.

Chen, S; (2005) "The impact of government regulation and ownership on the performance of securities companies: Evidences from China" Global Finance Journal, Volume 16 Issue 2, 113-124

Demir, N., Mahmud, S. F., \& Babuscu, S. (2005). The technical inefficiency effects of Turkish banks after financial liberalization. The Developing Economies, 43, 396-411.

Farrell, M.J. (1957). "The Measurement of Productive Efficiency." Journal of the Royal Statistical Society, Series A, 120,. 253-90.

Fukuyoma H., Weber W. L.(1999), The efficiency and productivity of Japanese securities firms, 1988 - 93. Japan and the World Economy, $11: 115-33$.

Hu, JL. \& Fang, CY (2010) Do market share and efficiency matter for each other? An application of the zero-sum gains data envelopment analysis, Journal of the Operational Research Society Volume 61, Issue 4, 647-657

Ihsan, I. V. (2007). Bank ownership and productivity developments: evidence from Turkey. Studies in Economics and Finance, 24, 115-139.

Isik, I. (2008). Productivity, technology and efficiency of de novo banks: a counter evidence from Turkey. Journal of Multinational Financial Management, 18, 427-442.

Kartal F. (2013) Development Of Capital Markets In Turkey And Analysıs Of Fınancıal Structure Of The Intermediary Instıtutıons, Eurasian Journal of Business and Management, 1(1), 1-14

Lee, D.-G., Kim, J., \& Kang, H. (2014). Do larger brokerage firms enjoy larger economies of scale and scope? Seoul Journal of Economics, 27, 445-467.

R.N.Serasinghe, M.B.P. Mahipala and L.H.P. Gunaratne(2003). Comparison of Stochastic Frontier Analysis (SFA) and Data Envelopment Analysis (DEA) to Evaluate Technical Efficiency: Tropical Agricultural Research Vol. IS: 217-225

Wang K.-L., Tseng Y.-T., Weng C.-C. (2003). A study of production efficiencies of integrated securities firms in Taiwan. Applied Financial Economics, 13:159-67. 